\title{
Brazil's football warriors: Social bonding and inter-group violence
}

Evolution and Human Behaviour

https://doi.org/10.1016/j.evolhumbehav.2018.06.010

Newson, Martha ${ }^{a^{*}}$

Bortolini, Tiago ${ }^{\text {bc }}$

Buhrmester, Michael $^{\mathrm{a}}$

Silva, Silvio Ricardo da ${ }^{\mathrm{d}}$

Aquino, Jefferson Nicássio Queiroga da ${ }^{\mathrm{d}}$

Whitehouse, Harvey ${ }^{\mathrm{a}}$

${ }^{a}$ Institute of Cognitive and Evolutionary Anthropology, University of Oxford. 51/53

Banbury Road, Oxford, OX2 6PE, United Kingdom

*martha.newson@anthro.ox.ac.uk (corresponding author)

$+44(0) 1865274678$

${ }^{\mathrm{b}}$ The D’Or Institute for Research and Education (IDOR), Rio de Janeiro, Brazil.

${ }^{\mathrm{c}}$ Graduate Program in Morphological Sciences, Federal University of Rio de Janeiro.

${ }^{\mathrm{d}}$ Departamento de Educação Fisica da Escola de Educação Física,

Fisioterapia e Terapia Ocupacional da UFMG, Belo Horizonte, Brazil

Football-related violence (hooliganism) is a global problem. Previous work has

proposed that hooliganism is an expression of social maladjustment. Here we test an 
alternative hypothesis, that hooliganism is typically motivated by a parochial form of prosociality, the evolutionary origins of which may lie in intergroup raiding and warfare. In a survey of Brazilian football fans $(N=465)$, results suggest that fan violence is fostered by intense social cohesion (identity fusion) combined with perceptions of chronic outgroup threats. In contrast, maladjustment is unrelated to indices of past acts of football-related violence or endorsement of future violence. Our results suggest that to reduce hooliganism and other forms of inter-group violence, efforts could be made to harness the extreme pro-group sentiments associated with identity fusion in more peaceful ways.

\section{Keywords}

Inter-group conflict; hooliganism; football violence; identity fusion; crowd control; altruism

\section{Introduction}


Football (or soccer) related violence (or 'hooliganism') is a persistent, global problem. Negative outcomes include injury, destruction of property, state security costs, and even death (Spaaij, 2005; Stott et al., 2008; Raspaud and da Cunha Bastos, 2013; Sekulic et al., 2015). To address the problem, we need to understand what motivates it in the first place.

For decades, hooliganism has been attributed to social 'maladjustment' or 'abnormal social functioning' (Lawther, 1972; Wakefield and Wann, 2006), sometimes associated with masculinity and class (Robson, 2000; Spaaij, 2008). By contrast, we argue here that football-related violence stems from a particularly potent form of progroup commitment dubbed "identity fusion" (Swann et al., 2009; Swann et al., 2012). People strongly fused to a group experience a profound sense of 'oneness' between their personal identity, that is who they are as an individual, and their social identity, e.g., family, religious affiliation, football team, etc. This synergy motivates a wide range of personally costly, pro-group actions because for fused persons, threats to the group are interpreted also as personal threats (Swann et al., 2010b; Swann et al., 2014; Whitehouse et al., 2014; Buhrmester et al., 2015). This 'warrior' psychology is consistent with evolutionary explanations of coalitional conflict and warfare (McDonald et al., 2012; Whitehouse et al., 2017). We present a warrior psychology hypothesis of football hooligans, i.e., that these fans are motived by identity fusion to defend their fellow fans in the face of perceived outgroup threats, using membership to Brazilian superfan groups (torcidas organizadas) as a proxy to assess threat. Here we attempt to adjudicate between 'social maladjustment' and evolved 'warrior psychology' hypotheses at the levels of both proximate and ultimate explanation. 
Football-related violence has often been attributed to social maladjustment, characterized by abnormal or impaired social functioning (Lawther, 1972; Zani and Kirchler, 1991; Wakefield and Wann, 2006). The 'hardened hooligan' is frequently depicted in mainstream media as a violent thug, gangster or other form of social deviant. This hooligan stereotype is also widely evident in popular books and films in the UK over the last two decades (Poulton, 2014).

Academic representations of football hooliganism emphasizing class (Dunning et al., 1986; Robson, 2000) and masculinity (Taylor, 1987; Spaaij, 2008) contribute to this popular caricature. According to this view, the typical hooligan is young, workingclass, troubled, and male (Zani and Kirchler, 1991; Wakefield and Wann, 2006). However, causal evidence in support of the social maladjustment hypothesis is scant. Contrary to popular parodies, research shows that football violence is not limited to the youth and the working classes (though they are perhaps most visible in the media) (Treadwell, 2006; Pearson and Stott, 2016).

\subsection{The warrior psychology hypothesis}

Some football fans experience a profound sense of 'oneness' between personal and social selves known as 'identity fusion' (Swann et al., 2009; Swann et al., 2012; Swann and Buhrmester, 2015; Newson, 2017). Dozens of studies focusing on a range of group alignments (e.g., national, political, religious) show that strongly 'fused' persons are willing to sacrifice themselves for fellow group members (Swann et al., 2014; Whitehouse et al., 2014; Buhrmester et al., 2015). This is due to the porous boundary between the personal and social selves of highly fused individuals and the fact that both personal and social selves of highly fused individuals are activated in tandem (Swann et al., 2010b). Likewise, fused individuals are emboldened by the sense that the group's collective strength is invested in their personal agency (Swann 
et al., 2012). As a result, highly fused people are extraordinarily committed to the group, as any attack on the group feels like an attack on oneself.

Fused individuals are not just co-operators; they regard one another as connected by family-like ties (Whitehouse and Lanman, 2014; Buhrmester et al., 2015). The extreme cooperation caused by fusion is thought to result in part from individuals recognising other group members as 'psychological kin' (or even closer than kin) due to sharing intense, self-transformative experiences and evolved tendencies for sacrificial behaviour to protect them (Swann et al., 2012; Whitehouse and Lanman, 2014; Jong et al., 2015; Newson et al., 2016; Whitehouse et al., 2017). Psychological kinship thus refers to fictive ties (e.g., as seen among 'fraternities' or 'brothers in arms'), as opposed to actual kin detection (e.g., via cohabiting with siblings or exposure to mother-infant dyads (Lieberman et al., 2007)).

While past work has shown that fusion with a group is sufficient to produce pro-group action, other group factors may interact with fusion to produce the particularly strong pro-group, violent acts that are found in certain highly fused groups (Swann et al., 2010a; Whitehouse et al., 2014; Sheikh et al., 2016). For instance, recent work with a sample of Israeli residents has also shown that individuals with high fusion scores are particularly hostile toward out-groups when they perceive high levels of threat to the ingroup (Fredman et al., 2017). The warrior psychology hypothesis is that football hooligans are motived by identity fusion to defend their fellow fans in the face of perceived outgroup threats, which are a continual feature of life for a member of a superfan group. 


\subsection{The evolutionary origins of hooliganism}

In trying to understand the root of football-related violence, scholarly attention has focused largely on proximate physiological mechanisms, such as post-match testosterone release (Bernhardt et al., 1998) or lower basal-cortisol levels in aggressive fans (van der Meij et al., 2015). Such explanations, though controversial, are not inconsistent with the social maladjustment hypothesis. It is less obvious, however, how a social maladjustment hypothesis might fit into a broader evolutionary account. By contrast, it is relatively easy to provide a rationale for the warrior psychology hypothesis at the level of ultimate functions in intergroup competition.

Research on the relationships between group membership, individual differences in violent behaviour, and fitness, have increasingly contributed to an understanding of intergroup conflict and warfare (Kurzban et al., 2001; Choi and Bowles, 2007; Navarrete et al., 2010; Wood, 2010; McDonald et al., 2012; Whitehouse et al., 2017). In particular, evolutionary approaches to the study of coalitional psychology have made considerable progress in understanding the phenomenon of fandom (Winegard and Deaner, 2010; Fessler et al., 2016).

Coalitionalism is a universal human trait. Examples include states, ethnic conflict, gang rivalries, male social-clubs, competitive team sports, and online video gaming. Coalitional psychology and intergroup violence are also documented in chimpanzee society (Goodall, 1986; Wilson et al., 2004), with coalitional aggression improving reproductive output (Gilby et al., 2013). Evolutionarily, we might expect to see higher levels of violence among male and masculinised groups due to a combination of male competition for access to females and the additional aggression required for intergroup conflict (Wrangham and Peterson, 1996; Pinker, 2011; McDonald et al., 2012). 
In phylogenetic terms, humans share the trait of male violence with other great apes (Pinker, 2011).

Football violence or 'hooliganism', in its many cultural settings, is best understood as a product of our evolved coalitional psychology, featuring aggression as a tool for group gain, hate and anger toward threatening out-groups (that could reduce fitness), and the ability to co-ordinate with the group (and potentially displaying this ability to increase the group's formidability; Tooby and Cosmides, 2010). Furthermore, in football, teams exhibit a number of non-sport-related traits that make them comparable to warring groups - players tend to: be connected with a particular territory; wear highly distinctive group uniforms, and; gain 'spoils' after the game, e.g., material wealth, status, and desirable mates (Winegard and Deaner, 2010).

Coalitional conflict has been explained in ultimate terms using evidence from gametheoretic analysis and agent-based simulations (Choi and Bowles, 2007). These analyses suggest that the volatile conditions of the late Pleistocene and early Holocene would have put selective pressures on altruism and parochialism in humans, due to conditions of heightened inter-group conflict. Clearly football has not existed long enough to influence evolution. Nonetheless, fan culture capitalises on our propensity to categorise and distinguish our coalitions. Just wearing a football shirt could be enough to alert others to one's coalitional affiliation, which in turn has been found to increase perceptions that the individual is both more physically formidable and aggressive (Fessler et al., 2016). Thus, an evolutionary framework can shed light on the role of group psychology in football hooliganism.

Recent research focusing specifically on the role of identity fusion in motivating extreme pro-group behaviour has modelled the evolutionary consequences of shared 
past experience for cooperation (Whitehouse et al., 2017). Specifically, models examined the extent to which groups facing dysphoric experiences (operationalized as fitness-reducing setbacks) are able to solve collective action problems, as compared with groups facing euphoric (fitness-enhancing) experiences (given standard assumptions regarding the transmission of genes that would make cooperation possible, but not inevitable). Following many simulations of this model, the gene effects for cooperation were found to be larger for dysphoric than euphoric experiences.

Empirical support for Whitehouse et al.'s model comes from surveys and experiments showing that dysphoric experiences with others lead to extreme social cohesion (identity fusion) in a diversity of sample populations ranging from military veterans, college fraternity / sorority members, martial arts practitioners, twins (beyond the effects of genetic relatedness), and football fans (Whitehouse et al., 2017). Of the 725 British football fans sampled by Whitehouse et al., those who were fans of loosing (dysphoria-inducing) teams were more likely to sacrifice themselves in a classic trolley dilemma, compared to fans of winning (euphoria-inducing) teams, an effect mediated by fusion. Furthermore, evolutionary advantages to the individual of engaging in personally costly, pro-group behaviours in inter-group conflict may be an outcome of direct reciprocity (Choi and Bowles, 2007) and indirect reciprocity and reputation enhancement (Fessler et al., 2016). Not all these possibilities have yet been integrated into fusion theory.

\subsection{Football Violence in Brazil}

A limitation of much previous research on issues of group membership and outgroup hostility is that studies have predominantly sampled participants from Western, 
Educated, Industrialized, Rich, and Democratic (i.e. 'WEIRD') populations, and nonWEIRD populations have been under-investigated (Henrich et al., 2010). Here we address this limitation by applying theories of coalitional conflict discussed above to a less WEIRD sample: Brazilian football fans and torcidas organizada members (groups of extreme fans; hooligans). Brazil, a developing nation, is culturally rich, ethnically diverse, and famed for its love of football, making it the ideal site for this research. Case studies report tight-knit networks of supporters and tales of camaraderie among hooligans (Francis and Walsh, 1997; Robson, 2000; Harvey and Piotrowska, 2013). These networks, rife with kin terminology, seem far removed from the social misfits and deviants implicated in maladjustment explanations of hooliganism. An alternative to the maladjustment hypothesis is the theory that shared dysphoria is a pathway to fusion.

In Brazil clashes between rival 'super fan' groups known as torcidas organizadas have become increasingly violent, resulting in injury, stadia bans, and imprisonments (Raspaud and da Cunha Bastos, 2013) as well as escalating loss of life (Murad, 2013; Raspaud and da Cunha Bastos, 2013). Membership to a torcida organizada entails persistent reminders of rivalries and the threats that one's rivals pose to the group's material successes, reputation, and security (de Toledo, 1996; Pimenta, 2000); such threats are both real and imagined and constitute an essential aspect of a torcida organizada's identity (Newson, 2017). For strongly fused persons, involvement in torcidas organizadas may embolden acts of hostility and self-sacrifice as efforts to defend one's psychological brothers-in-arms (Whitehouse et al., 2014; Fredman et al., 2017). In contrast, for persons strongly fused to their club's fellow fans but not involved in a super fan group, violence may be less prevalent because they tend to not perceive strong outgroup threats, relative to highly fused members of super fan 
groups. Here we examine the extent to which engaging in football violence is the result of the combination of membership in a torcida organizada and fusion to one's fellow fans.

\section{Hypotheses}

The purpose of this research was to test the following hypotheses, using a sample of football fans in Brazil $(N=465)$ :

(1) Social maladjustment is unrelated to past reports of football-related violence, willingness to fight/die, and membership in a torcida organizada;

(2) Instead, hooligan acts reflect an interaction between torcida organizada membership and fusion, such that highly fused torcida organizada members are especially more likely to be more violent and endorse fighting and dying for fellow fans;

(3) Fused torcida organizada members are especially likely to report violence against rival team fans compared to general fans, but there will not be significant differences between torcida organizada members and general fans concerning other targets (e.g., the police), suggesting that 'brothers in arms' are primarily battling opposing 'warriors'.

\section{Experimental Design}

For this study, we focused on Brazilian football fans of all major leagues. Using a snowball technique, our Brazilian partners distributed a 20-40 minute online questionnaire to affiliates of the Minerão stadium, surrounding fan groups, two subject pools, and posted on social media (e.g. Facebook, Twitter etc. and inviting 
people to 'share' / 'retweet' the study). Participants were told they could win one of three football jerseys of their club. This prize complied with Brazilian ethical regulations concerning no direct payment for participation in research. Ethical approval was obtained from the School of Anthropology and Museum of Ethnography Research Ethics Committee (SAME REC) in accordance with the procedures laid down by the University for ethical approval of all research involving human participants. Participants provided electronic informed consent by checking boxes on a screen in a similar fashion to check boxes on a printed document in Qualtrics.

Consent was recorded in the survey software and participants could not proceed to the main survey without reading and checking the consent pages.

The online survey consisted three sections: football-related questions and psychological measures; a simple but lengthy and boring behavioural task (to be published in a corresponding paper); and finally a social-adjustment test (SAS) and demographics. All participants completed Section 1, the results for which are presented below. As Section 2 was quite lengthy, only 250 participants of 439 went on to complete Section 3 containing the SAS (58.28\%). We compared our key variables from Section 1 between participants who completed the SAS and those who dropped out and found no reason to believe that they were categorically different. I.e., there were no observable differences between participants who completed the survey and those who dropped out before completing the SAS in terms of toricda organizada status, $\chi^{2}(1, N=439)=.36 p=.548$ or physical violence reported, $\chi^{2}(1$, $N=439)=0.002, p=.961$. Nor was there an observable difference in the composition of participants who did and did not complete the survey in terms of fusion $t(437)=-1.04, p=.299$ or willingness to fight $\&$ die for the group $t(437)=$ 
$0.16, p=.875$. We did not obtain data on which platform was used to complete the survey (e.g. smartphone or computer), but this may have contributed to attrition.

\subsection{Participants}

Of an initial 465 participants, 26 reported their sex as female, which created a heavily skewed sample. Thus only males were included in final analyses making $N=439$. Of the participants $\left(M_{\mathrm{age}}=25.72, \mathrm{SD}=8.02\right.$, range $\left.=18-63\right)$ who answered demographic variables, we found that fans: came from a range of states across Brazil (the most from São Paulo, 53.4\%; Minas Gerais, 14.2\%; 5-10\% from Paraná, Rio de Janeiro, Rio Grande do Sul; and less than 3\% from a number of other states); had mixed educational backgrounds (47.8\% completed middle school; $37.9 \%$ senior school; and $14.2 \%$ graduate school); and reported a range of incomes $(18.0 \%$ earned under $\mathrm{R} \$ 2364 ; 35.8 \% \mathrm{R} \$ 2364-34829$; and $46.2 \%$ over $\mathrm{R} \$ 4830)$. There was some racial variation in the sample, though the majority of participants were White (branco 73.9\%; Brown / pardo 15.4\%; Black / preto 5.1\%; Yellow / amarelo 1.2\%;

Indigenous $1.6 \%$; prefer not to say $2.8 \%$ ).

\subsection{Measures}

Items were presented in the following order. First we asked participants whether they self-identified as a member of a torcida organizada. We also asked participants whether they had ever been involved in fights related to football. If participants reported engaging in physical violence, we also asked them who these fights were with ('rival fans', 'police', 'other fans supporting one's own team', 'other').

Willingness to fight and die for fans of one's team was assessed using the 7-point Likert scale from -3 (strongly disagree) to 3 (strongly agree) (Swann et al., 2009) ( $\alpha$ 
$=.86$ ) adapted in (Bortolini et al., 2018). Items include: 'I would fight someone physically threatening another fan of my team', 'I would fight someone insulting or making fun of fans of my team as a whole', 'I would help other get revenge on someone who insulted fans of my team, 'Hurting other people is acceptable if it means protecting fans of my team', 'I'd do anything to protect fans of my team', 'I would sacrifice my life if it saved another fan's life' and 'I would sacrifice my life if it gave the fans of my team status or monetary reward'.

Identity fusion was assessed using the 7-point verbal scale (Gómez et al., 2011) in reference to the individual's fellow fans $(\alpha=.89)$ using the translations in (Bortolini et al., 2018). The items included: 'My fellow fans are me'; 'I am one with my fellow fans'; 'I feel immersed in my fellow fans',; 'I have a deep emotional bond with my fellow fans"'; 'I am strong because of my fellow fans'”; 'Ill do more for my fellow fans' than any other fan would' and; 'My fellow fans' makes me strong'.

We also included demographic measures and a version of the Self-report Social Adjustment Scale (SAS-SR) (Weissman and Bothwell, 1976) validated into Brazilian Portuguese (Gorenstein et al., 2002). The SAS-SR is a 54-item self-report measure of instrumental and expressive role performance at work, in social activities, and with family during the previous 2 weeks. The questions within each area cover four expressive and instrumental categories: performance at expected tasks; the amount of friction with people; finer aspects of interpersonal relations; and feelings and satisfactions. Each item in the SAS-SR is scored on a 5-point scale, the higher scores being indicative of greater impairment. It is a widely used and well-validated measure of social adjustment (Weissman, 1999). The SAS-SR comprises a number of sub-scales, of which only relevant categories are presented to the participant: work; 
school/education; spare time; single life; family life; interaction with partner; children; and marriage.

In addition, we also measured psychological kinship, as in previous studies of fusion it has been shown to mediate fusion's effect on outcomes. Psychological kinship was assessed using a three item scale $(\alpha=.90)$ (Buhrmester et al., 2015), again using Bortolini et al.'s translations. Items included: 'My group] is like family to me'; 'If a fellow [group member] is hurt or in danger, it is like a family member is hurt or in danger' and; 'I see fellow [group members] of my club as brothers and sisters'. However, when we examined the factor structure of the items in relation to fusion, the results were inconclusive. While a forced two factor solution clearly produced the expected separate fusion factor and psychological kinship factor, goodness of fit tests suggested that a single factor solution was more appropriate. Given this unclear outcome, we thought it prudent to not examine psychological kinship further in this paper.

\section{Results}

\subsection{Prevalence of violence}

Of the 439 participants, almost half (45.1\%) reported membership to a torcida organizada (see Table 2 for descriptives and Fig. 1 for a comparison of general fans and torcidas organizadas). A quarter of the total sample reported having engaged in football-related physical violence but this was significantly higher for those in a torcida organizada than general fans, $\chi^{2}(1)=49.30, p<.001$ (Fig. 1). Willingness to fight and die for other fans was also significantly higher for members of these extreme 
groups compared to general fans, $t(437)=-10.83, p<.001$, Cohen's $d=1.00$ (see Fig. 1 for a comparison).

Fig. 1

Differences between general fans and torcida organizada members

\section{Comparing super fans (torcida organizada members) and general fans}

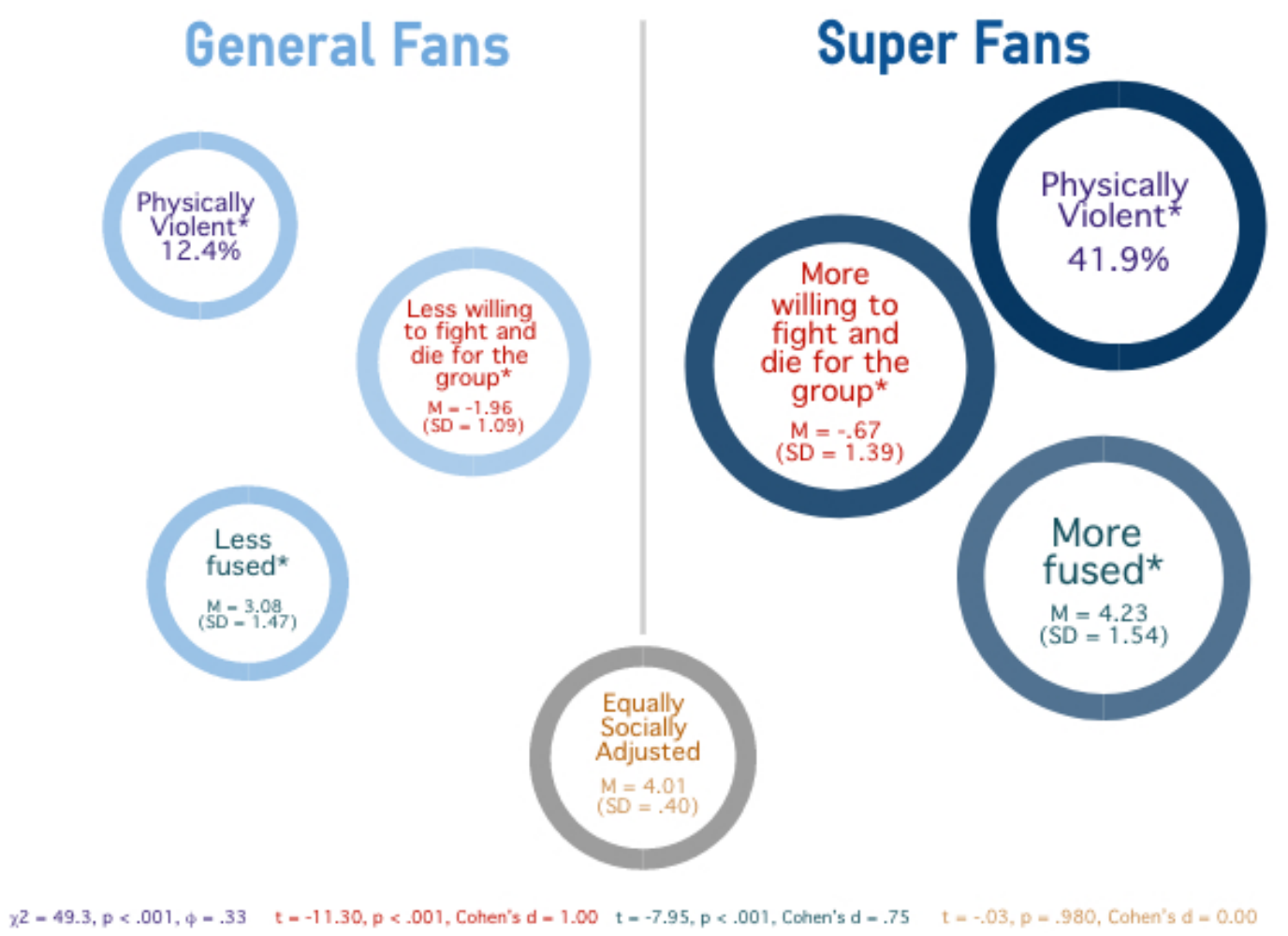

\subsection{Social maladjustment and violence}

We first tested whether football-related violence, willingness to fight and die for the group, and membership in a torcida organizada were connected to social maladjustment. After corrections for multiple comparisons $(p=.002)$, none of the SAS sub-scales correlated with our main variables of interest (see Tables 1 and 2 for correlations). There was no evidence to suggest that general fans $(M=4,01 S D=.40$, $N=138)$ were better socially adjusted than torcida organizada members $(M=4,01$ 
$S D=.40, N=104), t=-.03, p=.980$ (Fig. 1). Nor was there evidence for social maladjustment contributing to violence, a willingness to fight/die, or membership in a torcida organizada in a series of linear and logistic regressions (Table 3).

Table 1

Correlations between Social Adjustment Scale sub-items and key variables

\begin{tabular}{ccccc}
\hline SAS scales & Fusion & Fight and Die & Violence & SAS Total \\
\hline SAS Work & $.004(.963)$ & $.03(.787)$ & $-.01(.912)$ & $.544(<.001)^{*}$ \\
SAS School & $.05(.649)$ & $-.06(.557)$ & $-.02(.827)$ & $.574(<.001)^{*}$ \\
SAS Spare time & $-.05(.476)$ & $-.01(.856)$ & $.01(.835)$ & $.619(<.001)^{*}$ \\
SAS Single & $.16(.045)$ & $.09(.254)$ & $.04(.626)$ & $.667(<.001)^{*}$ \\
SAS Family & $-.04(.516)$ & $-.08(.258)$ & $-.08(.228)$ & $.639(<.001)^{*}$ \\
SAS Partner & $-.09(.514)$ & $-.21(.134)$ & $-.04(.757)$ & $.779(<.001)^{*}$ \\
SAS Children & $.01(.968)$ & $-.05(.810)$ & $.07(.722)$ & $.523(.001)^{*}$ \\
SAS Marriage & $-.18(.297)$ & $-.28(.091)$ & $-.20(.232)$ & $.739(<.001)^{*}$
\end{tabular}

*Bonferroni-corrected $p<.002$ 
Table 2

Descriptive statistics and correlations for identity fusion, fight and die, footballrelated violence (binary variable), score on the social adjustment scale, and psychological kinship

\begin{tabular}{llllll}
\hline Variables & 1 & 2 & 3 & 4 & 5
\end{tabular}

1. Fusion $\quad 3.60(1.60)$

2. Fight \& die $\quad .51(<.001)^{*} \quad-1.35(1.40)$

3. Violence $.28(<.001)^{*} \quad .47(<.001)^{*} \quad \mathrm{n} / \mathrm{a}$

4. SAS-SR $\quad .05(.486) \quad-.03(.692) \quad-.04(.496) \quad 4.01(.40)$

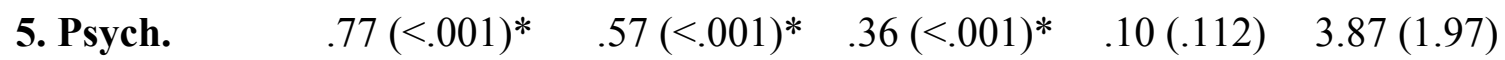

kinship

Note: Means and SD (in parentheses) on the diagonal, Pearson's r's and p-values (in parentheses) below the diagonal.

*Bonferroni-corrected $p<.005$

Table 3

Linear (1) and logistic (2-3) regressions with SAS-RS as the independent variable and fight \& die, physical violence, and TO membership as the dependent variables

\begin{tabular}{lcccccc}
\hline Model & B & S.E. & Wald & $p$ & Odds Ratio & 95\% CI \\
\hline 1. Fight \& Die & -.09 & .22 & - & .692 & - & - \\
2. Physical violence & -.25 & .37 & .47 & .494 & .78 & $.38,1.61$ \\
3. TO membership & .01 & .33 & .001 & .980 & 1.01 & $.53,1.92$ \\
\hline
\end{tabular}

Note:

Model $1 R^{2}=.001, F(240,1)=.16, \mathrm{p}=.692 ; \underline{\text { Model } 2}$ Nagelkerke $R^{2}=.003, \chi^{2}(1$, $240)=.465, p=.495 ;$ Model 3 Nagelkerke $R^{2}<.001, \chi^{2}(1,240)=.001, p=.980$ 
We ran a series of linear and logistic regressions to predict willingness to fight and die and physical violence respectively, including key demographic variables (age, education, income, region (dummy coded), and race (dummy coded) in Block 1 and adding mean fusion or SAS-RS in Block 2. Younger $(\beta=-.17, p=.018)$, less educated $(\beta=-.17, p=.022)$ individuals were most willing to fight and die for the group and participants reporting indigenous heritage were more willing to fight and die than the white reference group $(\beta=.19, p=.002), R^{2}=.14, F(234,11)=3.45, p<$ $.001, \Delta F=3.45$ ( $p$ of $\Delta F<.001)$, VIFs $<2.3$. When adding fusion $(\beta=.50, p<$ $.001)$ to the model, only the dummy coded indigenous variable remained a significant demographic predictor $(\beta=.13 p=.012), R^{2}=.37, F(233,12)=11.41, p<.001, \Delta F=$ 85.36 ( $p$ of $\Delta F<.001), \Delta \mathrm{R}^{2}=.23$, VIFs $<2.3$. No demographic variable reached significance in the physical violence model, but fusion was significant in Block 2 ( $B=$ $.41, p<.001)$, Nagelkerke $R^{2}=.22, \chi^{2}(233,12)=40.19, p<.001$. We found SAS scores to be non-significant in both models when entered into Block 2 instead of fusion $(\beta=.04, p=.596 ; B=.001, p=.801)$. Note that in all analyses, the effects of fusion on outcome variables remained significant after controlling for social identification, and in no case were effects of identification equal to or stronger than effects of fusion (see SI 1). This was also true for subsequent analyses.

\subsection{Identity fusion and violence}

Next we tested the hypothesis that hooligan acts (both past reports of football-related violence and endorsements of fighting/dying for one's club) reflect an interaction between torcida organizada membership and fusion, i.e., highly fused members would be especially likely to report hooligan acts. Indeed, in support of a social cohesion hypothesis, we found that fusion was significantly higher among torcida organizda members $(M=4.23, S D=1.54)$ than general fans $(M=3.08, S D=1.47), t$ 
$=-7.95, p<.001$, Cohen's $d=.75$ (Fig. 1). Next, we investigated whether fusion moderated the relationship between physical violence and membership to a torcida organizada by running a simple moderation analysis (ordinary least squares regression in Hayes's PROCESS v2.13.1 macro (Model 1) for SPSS v22 (Hayes, 2013) and bias-corrected bootstrap analyses based on a 5,000 bootstrap sample). Fusion $(b=.22, p=.011)$ and torcida organizada membership $(b=1.27, p<.001)$ both predicted physical violence, however, these main effects were qualified by their 2-way interaction $(b=.48, p=.005)$. Simple slopes analyses revealed that when fusion was low $(-1 S D)$, there was not a statistically significant effect of membership on violence, $b=.49, S E=.39, Z=1.26, p=.206$. When fusion was high $(+1 S D)$, there was an effect of membership on violence, $b=1.61, S E=.38, Z=5.32, p<.001$, such that highly fused torcida organizada members were especially likely to report physical violence (Fig. 2). 
Fig. 2

Interaction plots for torcida organizada status (IV) predicting the probability of having committed football-related physical violence in the past or willingness to fight and die in the future on a 1-7 scale (DVs) with fusion as a moderator
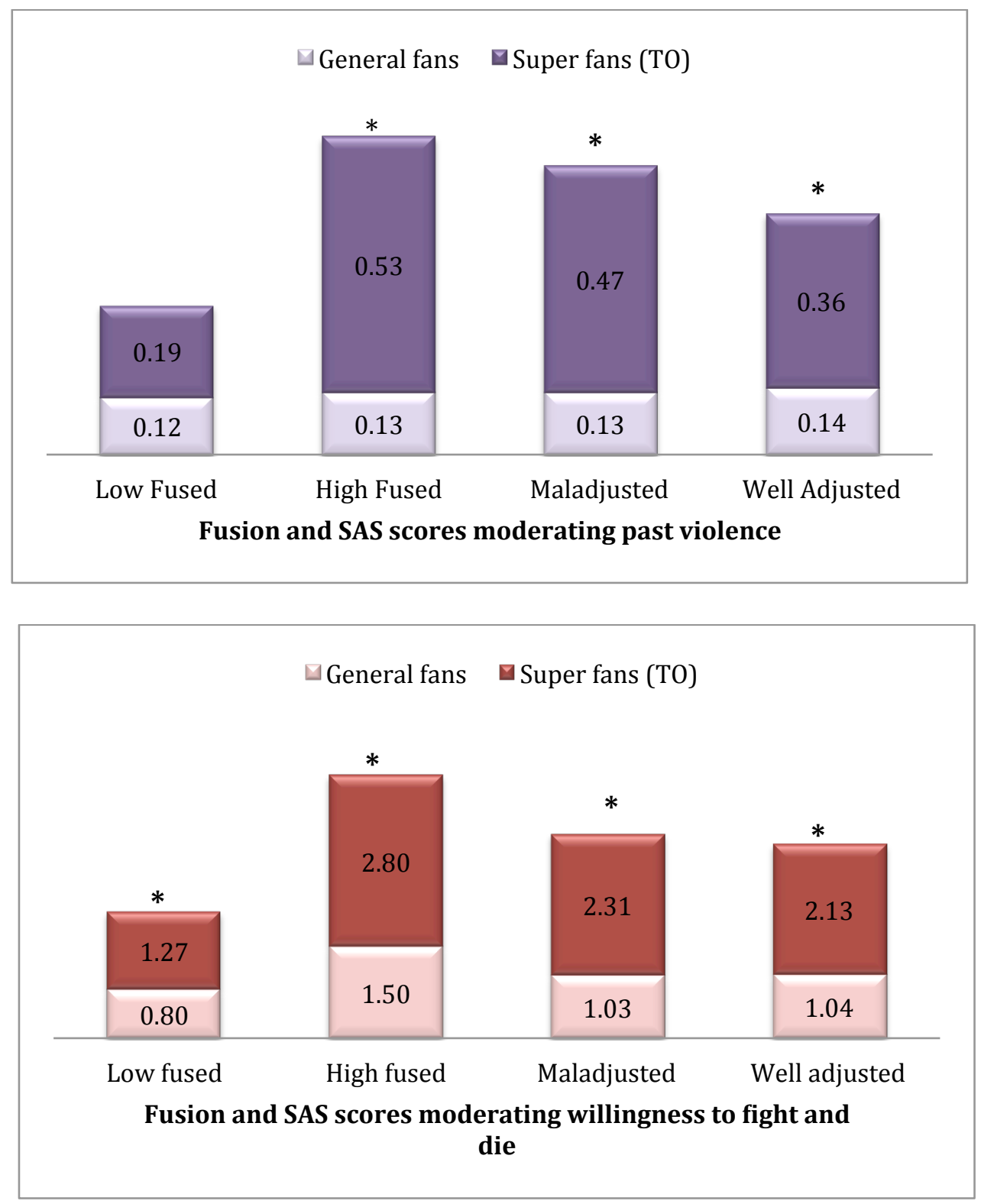

In contrast, there was neither an interaction between torcida organizada status and social adjustment $(b=-.66, p=.421)$, nor a main effect $(b=-.17, p=.697)$ of social 
adjustment, on reports of violence. Fig. 2 illustrates the fact that fused members of these extreme groups are particularly likely to have been in violent football altercations compared to weakly fused members. Highly fused members of these extreme groups were also more willing to fight and die for their groups in the future, compared to weakly fused group members (Fig. 2). Again, social maladjustment did not interact with membership to extreme groups.

Overall, these results suggest that in our sample, hooligan acts (both past violence reports and endorsements of future fighting/dying for one's club) are most likely to occur amongst strongly fused fans involved in extreme groups (torcidas organizadas) and that social maladjustment is unrelated to hooligan acts.

\subsection{Fusion and targeted outgroup violence}

Finally, we tested the hypothesis that (i) fused torcida organizada members are especially likely to report violence against rival team fans compared to general fans, and (ii) there are no significant differences between torcida organizada members and general fans concerning other targets (e.g., the police). Participants who reported having engaged in physical violence were asked to select whether they had fought with fans of a rival team, the police, fans of their own team, or an 'other' category (Table 4). We found evidence of a main effect for torcida organizada membership ( $b$ $=2.17, p=.001)$ predicting outgroup hostility, but only a marginal effect of fusion $(b$ $=.47, p=.063$ ). There was weak evidence of the main effect being qualified by the 2way interaction between fusion and group membership $(b=.76, p=.067)$ (Fig. 3). Simple slopes analyses revealed that for general fans there was not a statistically significant effect of fusion on violence, $b=-.09, S E=.25, Z=-.35, p=.724$. For torcida organizada members, there was an effect of fusion on violence, $b=.67, S E$ 
$=.33, Z=2.02, p=.043$, such that highly fused members were most likely to report violence. In support of the hypothesis, Fig. 3 indicates that in our sample fusion predicted violence toward an outgroup (rival fans), but fused torcida organizada members were particularly likely to report past violence to rival fans, compared to fused general fans.

Table 4

Contrasting targets of violence between general and super fans who reported engaging in football violence

\begin{tabular}{lccc}
\hline & General fans & Super fans & Statistic \\
\hline Rival fans & $65.3 \%$ & $92.8 \%$ & $\chi^{2}=14.94, p<.001, \varphi=.39$ \\
Police & $68.4 \%$ & $70.0 \%$ & $\chi^{2}=.02, p=.896, \varphi=.02$ \\
Own fans & $38.5 \%$ & $35.7 \%$ & $\chi^{2}=.03, p=.857, \varphi=.02$ \\
'Other' & $47.4 \%$ & $5.6 \%$ & $\chi^{2}=13.59, p<.001, \varphi=.52$ \\
\hline
\end{tabular}


Fig. 3

Interaction plot for torcida organizada status (IV) predicting violence to rival fans (DV) with fusion to fans as a moderator

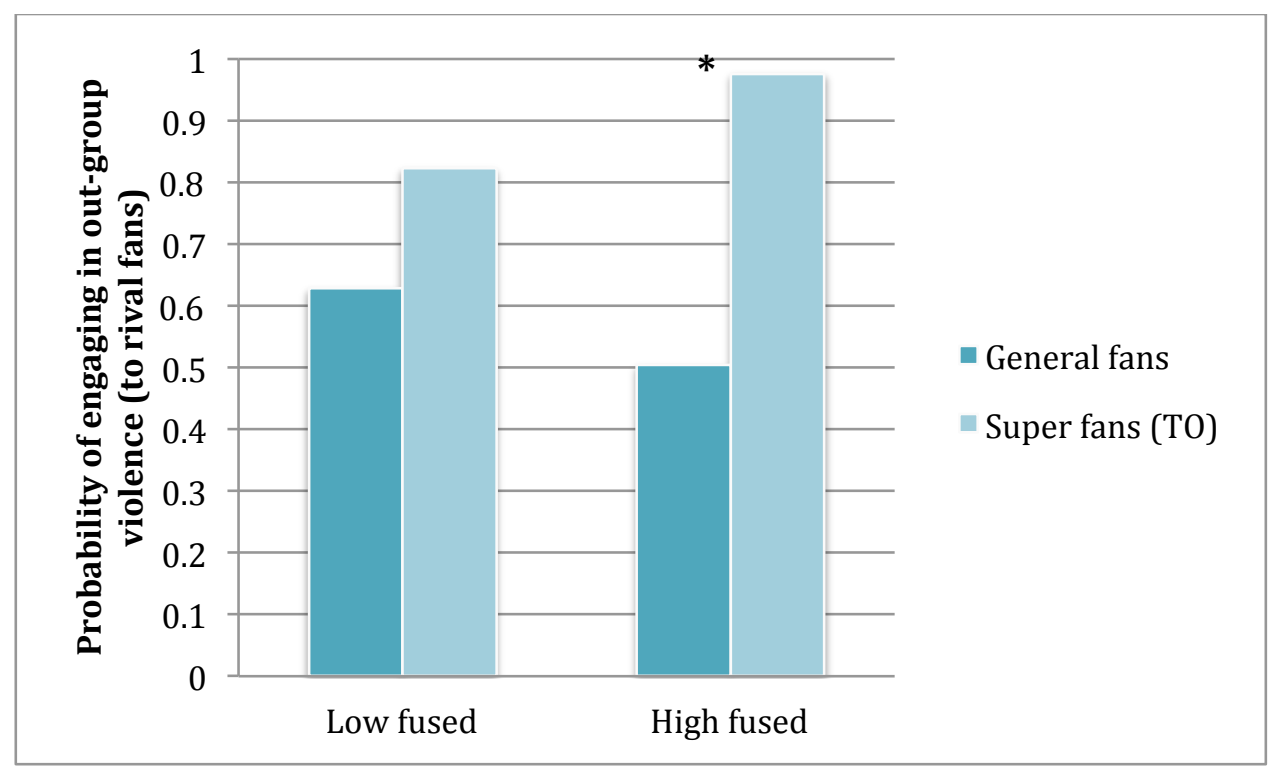

While violence toward other groups was reported, there were no main effects or fusion by group membership interactions for the other targets (violence toward the police, fans of own team, or 'other' e.g., family: $p>$.120), suggesting that torcida organizada members and general fans behaved similarly to other targets. These results suggest that membership of a torcida organizada drives the relationship between fusion and violence to specific outgroups.

\section{Discussion}

Our results indicate that both membership to a super-fan group, such as a torcida organizada, and identity fusion may play key roles in motivating violent behaviours among football fans. Our data suggest that rather than being socially maladjusted, a 
deep bond between fans motivates football hooliganism; to the extent that they regard one another as family. Furthermore, we found that it is the interaction between fusion to one's fellow fans and belonging to a super fan group that serves to ignite the violent behaviours associated with football hooliganism. Finally, we found evidence that violence perpetrated by member groups tended to be directed at specific outgroups, in contrast with the more indiscriminate violence exhibited by fans unaffiliated with a super fan group.

These findings are broadly consistent with theories on the evolution of coalitional conflict and extreme cooperation among non-kin (Kurzban et al., 2001; Choi and Bowles, 2007; Navarrete et al., 2010; Winegard and Deaner, 2010; McDonald et al., 2012; Fessler et al., 2016; Whitehouse et al., 2017). Our parochial altruism perspective may also complement the 'virtuous violence' argument. First, both views support the notion that belonging to a group entails socio-emotional and moral ties. Second, studies of virtuous violence suggest that violence can be both morally motivated and reflect cultural ideals (Fiske and Rai, 2014): indeed, humans use violence to constitute social relationships often (like in other species) to promote social cohesion or to organise dominance relationships. Future research examining the moral dimensions of conflict amongst fused persons in the football violence context could bear considerable fruit.

Proximately, at least two mechanisms potentially explain why strong fusion coupled with membership to a torcida organizada led to increased pro-group, violent outcomes in our study. First, perceptions of personal and group invulnerability (a common belief amongst highly fused persons) may be further heightened in torcidas 
organizadas because these groups tend to foster a super-machismo culture, promoting self-defence and notions of territory (Gómez et al., 2011; Swann et al., 2012).

Second, torcidas organizadas are likely to exist under conditions of chronic threat, compared to general fan populations. Although there is substantial cultural variation between torcidas organizadas - from those intertwined with violent Brazilian gang culture, to a minority of organisations that actively campaign against violence overall, torcidas organizadas are undoubtedly associated with violence (dos Reis et al., 2015). Rivalries and the perception of outgroup threats form an essential part of a torcida organizada's identity (de Toledo, 1996; Pimenta, 2000). In Brazil, these threats are acute and even life threatening (Murad, 2013; Raspaud and da Cunha Bastos, 2013). Threat perception has been linked to increased hostility among fused persons (Fredman et al., 2017) and also explains sex differences in hostility (Navarrete et al., 2010; Lizotte, 2017). Thus, when a strongly fused person enlists in one of these embattled groups, much like in a military unit, use of force in conflict may quickly become normalised, or even required. This account of threatening situations leading to extreme prosociality has both empirical and mathematical support (Whitehouse et al., 2017).

Coalitional psychology evolved to unify small-scale societies engaged in warfare and is thus a product of the intergroup violence that permeates human history (Boyd and Richerson, 2005; 2009). As yet, the proximate, cognitive mechanisms that actually bind group members have been left largely untouched. One area that has started to bridge this gap concerns the emotions that are required to shape behaviour in cooperative contexts (Fessler and Haley, 2003). These emotions include a number of group-based emotions, such as shame, pride, moral outrage, and moral approbation, as 
well as a number operating primarily in dyadic contexts (e.g. love, envy, anger). According to Fessler and Haley, if contemporary behaviour reflects biologically rational strategies from the ancestral past, our current suite of emotions were shaped by natural selection when humans lived in small, relatively stable social groups. Under such conditions, cooperation generated crucial benefits so these emotions are inferred to reduce defection by others and oneself. In a similar vein to Winegard and Deaner, Fessler and Haley suggest that solidarity among sports fans stems from culturally evolved cues that elicit corporate pride and shame (despite fans clearly knowing they are not really players in the game).

To complement this emotional-coalitional framing of fan behaviours, an understanding of fans' personal and group identities is also required. We propose that the intense form of social bonding found among football fans and many other highly bonded, often male, groups is a key factor in the extreme pro-group, often violent behaviours they exhibit. Enriching our current, ultimate understandings of coalitional conflict as outlined above, this paper provides evidence that identity fusion delivers a stronger framework to proximately explain football violence than either social maladjustment or identification.

The demographics associated with football fans and hooligans vary across nations, clubs and even intra-club fan groups. However, one relatively consistent factor is, perhaps unsurprisingly, sex. For example, even men's obituaries are significantly more likely to mention sports fan identification (15.2\%) than women's (5.2\%) (End et al., 2009). Although sex is not the focus of this paper, it is important to note that the relationship between sex and football violence is not unique to sport: Human males are reported to engage in more violence than females more broadly (Wrangham and 
Peterson, 1996). Further studies into sex differences concerning outgroup aggression and fusion should be revealing as to the evolution of coalitional conflict.

\subsection{Implications}

We found that our sample of fused torcida organizada members targeted other hooligan groups, rather than outgroups in general (such as the police or an 'other' category) when compared to fused general fans. Past research has identified that perceived external threat increases outgroup hostility in general (Brewer, 1999; Hewstone et al., 2002), but here we found that torcida organizada members directed their hostility only to specific rival fans and that this relationship between group membership and hostility to rivals was mediated by fusion. Members of other closely allied groups, such as gangs or terrorist cells, also target specific outgroups, or groups they perceive to be a threat to the group (and, if fused, consequently to themselves) (Whitehouse et al., 2014; Sheikh et al., 2016). Further research on the relationship between fusion and the construal of rival outgroups is urgently needed. Such research could help reduce the appearance of outgroup threats and the violent outcomes associated with it among Brazilian torcidas organizadas and other dangerous groups existing under conditions of chronic threat.

For fused individuals, this study supports the 'mother-bear' account of hostility (Fredman et al., 2017). Although fused individuals exhibit ingroup biases and are willing to sacrifice themselves for their groups (Swann et al., 2010a; Swann et al., 2014; Whitehouse et al., 2014; Joo and Park, 2017; Vázquez et al., 2017), here we showed that in a natural population, self-reported past violence among fused people tends to be toward specific outgroups that pose a threat to the group, i.e. rival fans. This may be due to the sense of psychological kinship found among fused group 
members, which promotes a 'brothers in arms' mentality, resulting in violent behaviours (Whitehouse et al., 2014; Buhrmester et al., 2015).

Evolutionarily, to have members of one's close-knit coalition be attacked comes at a cost to self, as these individuals would have been likely to share high levels of genetic relatedness, not to mention be implicated in reciprocal relationships. By bonding with one's group to as high a degree as if they were kin creates a proximate mechanism to allow groups to out-compete other groups in hostile environments, conferring group and individual-level advantages. This translates into modern coalitions, such as torcidas organizadas. Understanding the combination of a heightened sense of invulnerability experienced by fused people and the mother-bear effect may be critical to targeting successful interventions with other highly fused, more dangerous terrorist groups, e.g. far right extremists or Islamic radicalists.

As such, high levels of fusion in torcidas organizadas may also have positive social outcomes. There are sections of the general fan community who value the 'protective' role hooligans may play at matches, so called 'hoolifans' (Rookwood and Pearson, 2012). If this 'protection' could encompass the wider community, fusion might generate more socially acceptable pro-group behaviours, e.g., charity work. Future research could investigate super fans' highly choreographed, synchronised displays with a view to generalising pro-group behaviours - even toward outgroup members (Reddish et al., 2016). We do not intend to romanticise the hardened world of football hooliganism, but notice a gap - globally - from which to exploit the positives of extreme group bonding in an industry as globally and financially lucrative as football. 
This study extends previous work around the Elaborated Social Identity Model of Crowd Behaviour (ESIM) and taps into the extremity of fan behaviours that are found around the world. Already utilised by British police forces to combat hooliganism, the ESIM has been used to understand the presence and absence of football violence (Stott et al., 2001; Stott et al., 2007). Specifically, this proximate model proposes that the 'norms' of hooligan behaviour are an outcome of participants' shared social identity (Stott et al., 2008). As such, the model focuses on police force in constructing hooligan social identities, perceived legitimacy around violence, and 'self-regulation' among fan groups. The ESIM has strengths in explaining how situational focuses contribute to hooliganism, e.g. group membership results in shared norms around violence, but there are weaknesses when it comes to explaining individual differences.

Another variable for future research concerns sacred values, (values that take on transcendental significance and which, consequently, cannot be traded) and their relationship with fusion (Tetlock, 2003). Highly fused individuals who also hold sacred values have been found to be particularly likely to engage in extreme progroup action and are termed devoted actors (Atran, 2016). Such personally costly actions have been explained as allowing low-power groups to prevail against materially larger but ‘spiritually less formidable’ groups (Gómez et al., 2017), which could be relevant to the context of football violence.

The extreme Brazilian fans who participated in this study have counterparts across Latin America, most of Europe, and Australasia and our results speak to a global social problem. Further, football hooliganism may be representative of a broader class of destructive phenomena that are considered 'mindless destruction' by onlookers, such as the violence associated with spontaneous riots. For instance, the 2011 London 
riots which involved wide scale arson, vandalism, and multiple associated deaths are commonly attributed to structural causes (Lewis et al., 2011). Similarly the 2016 Charlotte and Milwaukee riots in the USA erupted following organised protests, resulting in injury, arson, and looting are broadly classified as race-based riots. While racism, classism, and economic decline may all play a role, so too may high fusion levels among the young males thought to have initiated the riots. If these people experienced the heightened state of invulnerability and increased agency associated with fusion (Gómez et al., 2011; Swann et al., 2012) and perceived the police shooting of a member of the community that immediately preceded all three of these riots to be an attack on kin (Swann et al., 2014; Buhrmester et al., 2015), then this disenfranchised group's already high levels of threat perception may have provided the lethal recipe that permitted days of destruction in these cities.

\subsection{Limitations}

Our study is not without limitations. First, although we found support for our hypothesized model of football violence as an interaction between fusion and super fan membership, it will take future work to identify the exact mechanisms underlying these effects. We also relied upon a convenience sample for our data, raising possible issues of representativeness. The survey was open to all to encourage variation and we achieved high levels of participation among a sample of self-described 'hooligans' who, because of past encounters with law enforcement, tend to be hesitant of participating in research. By surveying as wide a cross section of Brazilian football fans as we could and working closely with local researchers we were able to identify this special population. Follow up research will need to examine these issues and rule out the possibility of poor representation. 
One self-selection issue is that participants necessarily had Internet access, making them WEIRD to some extent, according to Henrich et al.'s definition (at least somewhat Western and Rich) (Henrich et al., 2010). Nonetheless, the prolific availability and reliance on smartphones in Brazil means that the much of the population now has Internet access, with at least $60 \%$ of Brazilians reporting owning a smartphone or accessing the Internet at least occasionally in 2015 (compared to 88\% and $89 \%$ in the UK and USA respectively) (Poushter, 2016). Future work accessing older generations and those living particularly rurally (e.g. hard to access indigenous populations) or in absolute poverty could extend this research by using pen and paper methods.

A caveat of this paper is that we cannot speak to the issue of whether violence that is reported was before or after torcida organizada membership as we did not include a time dimension. Though future research into whether there's a reciprocal relationship between violence and fusion is required to truly address this, we provide evidence that fusion strongly predicts future willingness to fight and die for the group. This supports a large body of research that fusion predicts willingness to fight and die, e.g. in controlled lab studies with Spanish and American citizens, and with Libyan revolutionaries in the field (Swann et al., 2010a; Swann et al., 2010b; Gómez et al., 2011; Whitehouse et al., 2014). Furthermore, fusion is highly stable over time (Swann et al., 2012; Fredman et al., 2015), so it is highly likely that fusion in the present for these participants is likely to their fusion levels at the times they report violence (whether that is recent or years ago). 


\section{Conclusions}

We cannot say that either decreasing fusion or membership to extreme groups will stop football-related violence. Rather than 'defusing' the group, which may be unrealistic given the irrevocable nature of fusion (Fredman et al., 2015), another possibility is to encourage fusion to groups that place less emphasis on intergroup rivalries and experience lower levels of outgroup threat. Further, brutal police tactics may only serve to increase hostility by inflating perceived threat levels toward the ingroup. Extreme tactics such as the use of tear gas or deployment of military personal may create enduring, 'self-stransformative' experiences that only further fuse the individual to the group (Newson et al., 2016). We hope this study spurs an interest in reducing inter-group conflict through a deeper understanding of both evolved psychological and situational factors. Indeed, a number of scholars are investigating such mechanisms and designing interventions for conflict reduction (Whitehouse et al., 2013).

\section{Data Availability}

The data associated with this research are available at [link]. 


\section{References}

ATRAN, S. 2016. The devoted actor: unconditional commitment and intractable conflict across cultures. Current Anthropology, 57, S000-S000.

BERNHARDT, P. C., DABBS JR, J. M., FIELDEN, J. A. \& LUTTER, C. D. 1998. Testosterone changes during vicarious experiences of winning and losing among fans at sporting events. Physiology \& Behavior, 65, 59-62.

BORTOLINI, T., NEWSON, M., NATIVIDADE, J., VÁZQUEZ, A. \& GÓMEZ, Á. 2018. Dying for my Country, my Religion, or my Football Team: Identity Fusion Predicts Progroup Behaviour for Brazilian Portuguese. British Journal of Social Psychology.

BOYD, R. \& RICHERSON, P. J. 2005. Solving the puzzle of human cooperation. Evolution and culture, 105-132.

BOYD, R. \& RICHERSON, P. J. 2009. Culture and the evolution of human cooperation. Philosophical Transactions of the Royal Society B: Biological Sciences, 364, 32813288.

BREWER, M. B. 1999. The psychology of prejudice: Ingroup love and outgroup hate? Journal of social issues, 55, 429-444.

BUHRMESTER, M. D., FRASER, W. T., LANMAN, J. A., WHITEHOUSE, H. \& SWANN, W. B. 2015. When terror hits home: Identity fused Americans who saw Boston bombing victims as "family" provided aid. Self and Identity, 14, 253-270.

CHOI, J.-K. \& BOWLES, S. 2007. The coevolution of parochial altruism and war. science, $318,636-640$.

DE TOLEDO, L. H. 1996. Torcidas organizadas de futebol, Autores Associados.

DOS REIS, H., LOPES, F. \& MARTINS, M. 2015. Eric Dunning's explanations about hooliganism in the Brazilian context: a critical review. Movimento, 21, 617-632.

DUNNING, E., MURPHY, P. \& WILLIAMS, J. 1986. Spectator Violence at Football Matches: Towards a Sociological Explanation. The British Journal of Sociology, 37, 221-244.

END, C. M., MEINERT, J. L., JR., WORTHMAN, S. S. \& MAUNTEL, G. J. 2009. Sport fan identification in obituaries. Percept Mot Skills, 109, 551-554.

FESSLER, D. \& HALEY, K. J. 2003. The strategy of affect: Emotions in human cooperation 12. The Genetic and Cultural Evolution of Cooperation, P. Hammerstein, ed, 7-36.

FESSLER, D. M., HOLBROOK, C. \& DASHOFF, D. 2016. Dressed to kill? Visible markers of coalitional affiliation enhance conceptualized formidability. Aggressive behavior, 42, 299-309.

FISKE, A. P. \& RAI, T. S. 2014. Virtuous violence: Hurting and killing to create, sustain, end, and honor social relationships, Cambridge University Press.

FRANCIS, M. \& WALSH, P. 1997. Guvnors: The Autobiography of a Football Hooligan Gang Leader, Milo Books.

FREDMAN, L. A., BASTIAN, B. \& SWANN JR, W. B. 2017. God or Country? Fusion With Judaism Predicts Desire for Retaliation Following Palestinian Stabbing Intifada. Social Psychological and Personality Science, 1948550617693059.

FREDMAN, L. A., BUHRMESTER, M. D., GOMEZ, A., FRASER, W. T., TALAIFAR, S., BRANNON, S. M. \& SWANN, W. B. 2015. Identity Fusion, Extreme Pro-Group Behavior, and the Path to Defusion. Social and Personality Psychology Compass, 9, 468-480.

GILBY, I. C., BRENT, L. J., WROBLEWSKI, E. E., RUDICELL, R. S., HAHN, B. H., GOODALL, J. \& PUSEY, A. E. 2013. Fitness benefits of coalitionary aggression in male chimpanzees. Behavioral Ecology and Sociobiology, 67, 373-381.

GÓMEZ, Á., BROOKS, M. L., BUHRMESTER, M. D., VÁZQUEZ, A., JETTEN, J. \& SWANN JR, W. B. 2011. On the nature of identity fusion: Insights into the construct and a new measure. Journal of Personality and Social Psychology, 100, 918-933. 
GÓMEZ, Á., LÓPEZ-RODRÍGUEZ, L., SHEIKH, H., GINGES, J., WILSON, L., WAZIRI, H., VÁZQUEZ, A., DAVIS, R. \& ATRAN, S. 2017. The devoted actor's will to fight and the spiritual dimension of human conflict. Nature Human Behaviour, 1.

GOODALL, J. 1986. Social rejection, exclusion, and shunning among the Gombe chimpanzees. Ethology and Sociobiology, 7, 227-236.

GORENSTEIN, C., MORENO, R., BERNIK, M., CARVALHO, S., NICASTRI, S., CORDAS, T., CAMARGO, A., ARTES, R. \& ANDRADE, L. 2002. Validation of the Portuguese version of the Social Adjustment Scale on Brazilian samples. Journal of affective disorders, 69, 167-175.

HARVEY, A. \& PIOTROWSKA, A. 2013. Intolerance and joy, violence and love among male football fans: towards a psychosocial explanation of 'excessive' behaviours. Sport in Society, 16, 1404-1413.

HENRICH, J., HEINE, S. J. \& NORENZAYAN, A. 2010. Beyond WEIRD: Towards a broadbased behavioral science. Behavioral and Brain Sciences, 33, 111-135.

HEWSTONE, M., RUBIN, M. \& WILLIS, H. 2002. Intergroup bias. Annual review of psychology, 53, 575-604.

JONG, J., WHITEHOUSE, H., KAVANAGH, C. \& LANE, J. 2015. Shared Negative Experiences Lead to Identity Fusion via Personal Reflection. PLoS One, 10.

JOO, M. \& PARK, S. W. 2017. Effect of identity fusion on decision to make extreme sacrifices in romantic relationships: The moderating role of impulsiveness. British Journal of Social Psychology.

KURZBAN, R., TOOBY, J. \& COSMIDES, L. 2001. Can race be erased? Coalitional computation and social categorization. Proceedings of the National Academy of Sciences, 98, 15387-15392.

LAWTHER, J. D. 1972. Sport psychology, Prentice-Hall.

LEWIS, P., NEWBURN, T., TAYLOR, M., MCGILLIVRAY, C., GREENHILL, A., FRAYMAN, H. \& PROCTOR, R. 2011. Reading the riots: investigating England's summer of disorder.

LIEBERMAN, D., TOOBY, J. \& COSMIDES, L. 2007. The architecture of human kin detection. Nature, 445, 727-731.

LIZOTTE, M.-K. 2017. Gender Differences in Support for Torture. Journal of Conflict Resolution, 61, 772-787.

MCDONALD, M. M., NAVARRETE, C. D. \& VAN VUGT, M. 2012. Evolution and the psychology of intergroup conflict: The male warrior hypothesis. Phil. Trans. $R$. Soc. B, 367, 670-679.

MURAD, M. 2013. Práticas de violência e mortes de torcedores no futebol brasileiro. Revista USP, 139-152.

NAVARRETE, C. D., MCDONALD, M. M., MOLINA, L. E. \& SIDANIUS, J. 2010. Prejudice at the nexus of race and gender: an outgroup male target hypothesis. Journal of personality and social psychology, 98, 933.

NEWSON, M. 2017. Football, Fan Violence, and Identity Fusion. International Review for the Sociology of Sport.

NEWSON, M., BUHRMESTER, M. \& WHITEHOUSE, H. 2016. Explaining Lifelong Loyalty: The Role of Identity Fusion and Self-Shaping Group Events. PloS one, 11, e0160427.

PEARSON, G. \& STOTT, C. 2016. Farewell to the hooligan? Modern developments in football crowd management. In: SCHULENKORF, N. \& FRAWLEY, S. (eds.) Critical Issues in Global Sport Management. Oxford: Routeledge.

PIMENTA, C. A. M. 2000. Violência entre torcidas organizadas de futebol. São Paulo em perspectiva, 14, 122-128.

PINKER, S. 2011. The better angels of our nature: The decline of violence in history and its causes, Penguin uk.

POULTON, E. 2014. The hooligan film factory: Football violence in high definition. Football hooliganism, fan behaviour and crime: Contemporary issues, 154-175. 
POUSHTER, J. 2016. Smartphone ownership and internet usage continues to climb in emerging economies. Pew Research Center, 22, 1 - 44.

RASPAUD, M. \& DA CUNHA BASTOS, F. 2013. Torcedores de futebol: violence and public policies in Brazil before the 2014 FIFA World Cup. Sport in Society, 16, 192-204.

REDDISH, P., TONG, E. M., JONG, J., LANMAN, J. A. \& WHITEHOUSE, H. 2016. Collective synchrony increases prosociality towards non-performers and outgroup members. British Journal of Social Psychology.

ROBSON, G. 2000. 'No one likes us, we don't care': the myth and reality of Millwall fandom, Berg Publishers.

ROOKWOOD, J. \& PEARSON, G. 2012. The hoolifan: Positive fan attitudes to football 'hooliganism'. International review for the sociology of sport, 47, 149-164.

SEKULIC, M., KÜHL, S., CONNERT, T., KRASTL, G. \& FILIPPI, A. 2015. Dental and jaw injuries sustained by hooligans. Dental traumatology, 31, 477-481.

SHEIKH, H., GÓMEZ, Á. \& ATRAN, S. 2016. Empirical evidence for the devoted actor model. Current Anthropology, 57, S000-S000.

SPAAIJ, R. The prevention of football hooliganism: A transnational perspective. Actas del X Congreso Internacional de Historia del Deporte. Seville: CESH, 2005. 1-10.

SPAAIJ, R. 2008. Men like us, boys like them violence, masculinity, and collective identity in football hooliganism. Journal of sport \& social issues, 32, 369-392.

STOTT, C., ADANG, O., LIVINGSTONE, A. \& SCHREIBER, M. 2007. Variability in the collective behaviour of England fans at Euro2004:'Hooliganism', public order policing and social change. European journal of social psychology, 37, 75-100.

STOTT, C., ADANG, O., LIVINGSTONE, A. \& SCHREIBER, M. 2008. Tackling football hooliganism: A quantitative study of public order, policing and crowd psychology. Psychology, Public Policy, and Law, 14, 115.

STOTT, C., HUTCHISON, P. \& DRURY, J. 2001. 'Hooligans' abroad? Inter-group dynamics, social identity and participation in collective 'disorder' at the 1998 World Cup Finals. British Journal of Social Psychology, 40, 359-384.

SWANN, W. B. \& BUHRMESTER, M. D. 2015. Identity Fusion. Current Directions in Psychological Science, 24, 52-57.

SWANN, W. B., BUHRMESTER, M. D., GÓMEZ, A., JETTEN, J., BASTIAN, B., VÁZQUEZ, A., ARIYANTO, A., BESTA, T., CHRIST, O. \& CUI, L. 2014. What makes a group worth dying for? Identity fusion fosters perception of familial ties, promoting selfsacrifice. Journal of personality and social psychology, 106, 912.

SWANN, W. B., GÓMEZ, Á., DOVIDIO, J. F., HART, S. \& JETTEN, J. 2010a. Dying and Killing for One's Group: Identity Fusion Moderates Responses to Intergroup Versions of the Trolley Problem. Psychological Science, 21, 1176-1183.

SWANN, W. B., GÓMEZ, Á., HUICI, C., MORALES, J. F. \& HIXON, J. G. 2010b. Identity fusion and self-sacrifice: Arousal as a catalyst of pro-group fighting, dying, and helping behavior. Journal of Personality and Social Psychology, 99, 824-841.

SWANN, W. B., GÓMEZ, Á., SEYLE, D. C., MORALES, J. F. \& HUICI, C. 2009. Identity fusion: The interplay of personal and social identities in extreme group behavior. Journal of Personality and Social Psychology, 96, 995-1011.

SWANN, W. B., JETTEN, J., GÓMEZ, Á., WHITEHOUSE, H. \& BASTIAN, B. 2012. When group membership gets personal: A theory of identity fusion. Psychological Review, 119, 441-456.

TAYLOR, I. 1987. Putting the Boot Into a Working-Class Sport: British Soccer After Bradford and Brussels. Sociology of Sport Journal, 4.

TETLOCK, P. E. 2003. Thinking the unthinkable: Sacred values and taboo cognitions. Trends in cognitive sciences, 7, 320-324.

TOOBY, J. \& COSMIDES, L. 2010. Groups in mind: The coalitional roots of war and morality. In: HØGH-OLESEN, H. (ed.) Human morality and sociality: Evolutionary and comparative perspectives. Palgrave-Macmillan. 
TREADWELL, J. 2006. Football Hooliganism [book review]. Probabtion Journal, 53, 186 187.

VAN DER MEIJ, L., KLAUKE, F., MOORE, H. L., LUDWIG, Y. S., ALMELA, M. \& VAN LANGE, P. A. 2015. Football Fan aggression: the importance of low basal cortisol and a fair referee. PloS one, 10, e0120103.

VÁZQUEZ, A., GÓMEZ, Á., ORDOÑANA, J. R., SWANN, W. B. \& WHITEHOUSE, H. 2017. Sharing genes fosters identity fusion and altruism. Self and Identity, 1-19.

WAKEFIELD, K. L. \& WANN, D. L. 2006. An examination of dysfunctional sport fans: Method of classification and relationships with problem behaviors. Journal of Leisure Research, 38, 168.

WEISSMAN, M. M. 1999. Social Adjustment Scale-self Report (SAS-SR): User's Manual, Multi-Health Systems.

WEISSMAN, M. M. \& BOTHWELL, S. 1976. Assessment of social adjustment by patient self-report. Archives of general psychiatry, 33, 1111-1115.

WHITEHOUSE, H., JONG, J., BUHRMESTER, M., GOMEZ, A., BASTIAN, B., KAVANAGH, C., NEWSON, M., MATTHEWS, M., LANMAN, J. A., MCKAY, R. \& GAVRILETS, S. 2017. The evolution of extreme cooperation via shared dysphoric experiences. Nature: Scientfic reports.

WHITEHOUSE, H. \& LANMAN, J. A. 2014. The Ties That Bind Us: Ritual, fusion, and identification. Current Anthropology, 55, 674-695.

WHITEHOUSE, H., MCQUINN, B., BUHRMESTER, M. \& SWANN, W. B. 2014. Brothers in arms: Libyan revolutionaries bond like family. Proceedings of the National Academy of Sciences, 111, 17783-17785.

WHITEHOUSE, H., SWANN, W., INGRAM, G., PROCHOWNIK, K., LANMAN, J., WARING, T. M., FROST, K., JONES, D., REEVE, Z. \& JOHNSON, D. 2013. Three Wishes for the World (with comment). Cliodynamics: The Journal of Theoretical and Mathematical History, 4.

WILSON, M. L., WALLAUER, W. R. \& PUSEY, A. E. 2004. New cases of intergroup violence among chimpanzees in Gombe National Park, Tanzania. International Journal of Primatology, 25, 523-549.

WINEGARD, B. \& DEANER, R. O. 2010. The evolutionary significance of Red Sox nation: sport fandom as a by-product of coalitional psychology. Evol Psychol, 8, 432-446.

WOOD, J. C. 2010. A change of perspective: integrating evolutionary psychology into the historiography of violence. The British Journal of Criminology, 51, 479-498.

WRANGHAM, R. W. \& PETERSON, D. 1996. Demonic males: Apes and the origins of human violence, Houghton Mifflin Harcourt.

ZANI, B. \& KIRCHLER, E. 1991. When violence overshadows the spirit of sporting competition: Italian football fans and their clubs. Journal of Community \& Applied Social Psychology, 1, 5-21. 


\section{Supplementary Information}

\section{Controlling for identification}

We also included a single-item measure of group identification (Postmes, 2013) in reference to fellow fans. Although a multi-item measure would be preferable for comparison, we were cautious of participant fatigue. In all cases, the effects of fusion on outcome variables remained significant after controlling for identification, and in no case were effects of identification equal to or stronger than effects of fusion. These analyses support our perspective that identity fusion theory provides the most robust framework for understanding the effects obtained.

First, we re-ran the initial moderation analyses with torcida organizada status as the independent variable, violence / fight and die the dependent variable, fusion the moderator, and identification as a covariate. Identification was not a significant predictor of violence in the model $(b=.11, p=.178 ; b=-.004, p=.891)$ and the interaction between fusion and torcida organizada status was still significant $(b=.60$, $p=.006 ; b=.24, p=.004)$. We also ran the model replacing fusion with identification and found that identification did not predict violence $(b=.06, p=.507$; $b=.001, p=.988)$ but there was a significant interaction between identification and torcida organizada status $(b=.33, p=.030 ; b=.17, p<.001)$.

We then performed a logistic regression with out-group violence as the dependent variable, and fusion to fans, torcida organizada status, identification with fans, the interaction between fusion and torcida organizada status, and the interaction between identification and torcida organizada status as independent variables. The logistic regression indicated that the interaction term torcida organizada status $\mathrm{x}$ fusion to fans predicted violence to rival fans Nagelkerke's $R^{2}=.26, \chi^{2}(5,115)=$ $11.18, p=.048, \mathrm{VIFs}<1.7($ SI Table 1$)$. 
SI Table 1

Simultaneous logistic regression to predict out-group violence

\begin{tabular}{|c|c|c|c|c|c|c|c|}
\hline \multirow[t]{2}{*}{ Variables } & \multirow[t]{2}{*}{ B } & \multirow[t]{2}{*}{ SE } & \multirow[t]{2}{*}{ Wald } & \multirow[t]{2}{*}{$p$} & \multirow[t]{2}{*}{ Odds Ratio } & \multicolumn{2}{|c|}{ 95\% C.I.for Odds Ratio } \\
\hline & & & & & & Lower & Upper \\
\hline Fusion & -.50 & .40 & 1.53 & .217 & .61 & .28 & 1.34 \\
\hline TO status & 1.24 & 3.81 & 0.11 & .744 & 3.46 & .002 & 5992.93 \\
\hline Fusion $\mathrm{x}$ TO & 1.15 & .55 & 4.29 & $.038^{*}$ & 3.14 & 1.06 & 9.28 \\
\hline Id. & .28 & .30 & 0.85 & .356 & 1.32 & .73 & 2.38 \\
\hline Id. X TO & -.50 & .48 & 1.07 & .302 & .61 & .24 & 1.56 \\
\hline Constant & .24 & 1.74 & 0.02 & .889 & 1.28 & & \\
\hline
\end{tabular}

